\title{
Proteus the Sealherd (Callim. SH Frag. 254. 6)
}

\section{Citation}

Thomas, Richard F. 1986. Proteus the sealherd (Callim. SH Frag. 254. 6). Classical Philology 81(4): 319.

\section{Published Version}

doi:10.1086/367008

\section{Permanent link}

http://nrs.harvard.edu/urn-3:HUL.InstRepos:3757040

\section{Terms of Use}

This article was downloaded from Harvard University's DASH repository, and is made available under the terms and conditions applicable to Other Posted Material, as set forth at http:// nrs.harvard.edu/urn-3:HUL.InstRepos:dash.current.terms-of-use\#LAA

\section{Share Your Story}

The Harvard community has made this article openly available.

Please share how this access benefits you. Submit a story.

Accessibility 
To go on would be to labor the point unduly. It remains a tenable proposition that Aristophon's political activity in the 390s, 380s, and 370s was less intense than we know it to have been both earlier and, especially, later. But it is equally reasonable to continue to envisage some degree of continuity - which may one day be better attested - between the two well-documented phases of his career. ${ }^{35}$

\section{DAVID WHITEHEAD University of Manchester}

35. My friend Mogens Herman Hansen was kind enough to criticize an early draft of this article. I have ventured to disagree with his specific observations at times, but I can claim his agreement with the general thrust of my argument.

PROTEUS THE SEALHERD (CALLIM. SH FRAG. 254. 6)

Early in the Victoria Berenices Callimachus announces, in characteristically periphrastic manner, that word of his queen's success has just arrived in Egypt ( $S H$ frag. 254. 5-6):

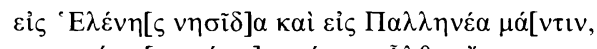

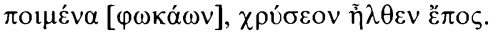

That is, the report has come to the island of Pharos, and to Proteus. $\mathrm{H}$. Lloyd-Jones supports his supplement, $\varphi \omega \kappa \alpha ́ \omega v$, by referring to Homer Odyssey 4. 411-13, where the nymph Eidothea informs Menelaus that he will find Proteus

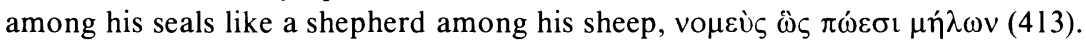
Although this is not quite as bold as the outright designation $\pi$ ou$\mu \varepsilon \dot{v} \alpha \varphi \omega \kappa \alpha \omega v$, the conjecture is nevertheless unassailable, for at Georgics 4. 395, in a passage closely modeled on the entire sequence from Odyssey 4, and shortly before he adapts and expands the same Homeric simile (433 uelut stabuli custos . . .), Vergil has Cyrene (the modified Eidothea) describe Proteus' activities: pascit . . phocas. In other words he is a pastor phocarum. That Vergil is recalling Callimachus seems beyond doubt, since his lines resemble those of Callimachus and differ from the Homeric archetype in two other ways: he twice $(387,392)$ calls him uates (cf. $\mu \alpha \dot{v} \tau \iota v$, frag. 254. 5); ${ }^{1}$ and he associates him with Pallene (390-91 patriamque reuisit / Pallenen). ${ }^{2}$

Vergilius ecce iterum conflat.

RICHARD F. THOMAS

University of Cincinnati

1. The attribution is not made by Homer; indeed, in stressing the prophetic qualities of Proteus at G. 4 . 392-93 "nouit namque omnia uates, / quae sint, quae fuerint, quae mox uentura trahantur," Vergil leaves his Odyssean model and translates the description of Chalcas, the chief Homeric seer, at $I l .1 .70$ ö $\zeta \eta^{\prime} \delta \eta$

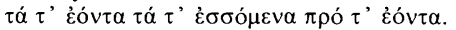

2. As only Lycophron (Alex. 126-27) and, as we can now see, Callimachus had done before Vergil. I suspect Lycophron brought the variant with him when he moved from Chalcis to Alexandria; Vergil's claim that Proteus is visiting his fatherland in Chalcidic Pallene (contradicting Lycophron's claim that the fatherland is Egypt) may provide a vestige of some scholarly dueling between the two Alexandrians, with Vergil naturally supporting Callimachus. 